\title{
Impact of Industry, operations in foreign currency, type of ownership on Comprehensive Income - The case of Egyptian companies
}

\author{
Dr. Afaf Mubarak \\ Lecturer of Accounting \\ Faculty of Commerce \\ Beni Suef University, Egypt
}

\begin{abstract}
:
The Egyptian companies are required to prepare the comprehensive income statement recently (one year only). This study thought to explore the practice and its details and some effects via comparing between the effects of net income and comprehensive income in changes in share price. Data collected for companies listed in Cairo Securities Exchange for the financial year 2016/2017. The results support the main hypothesis which is, comprehensive income more related to share price than net income. Details show that the situation differs by industry and ownership. The results are stronger in banks and the financial sector and industrial companies rather than a sector like food or tourism. Companies of the private sector showed more influential impact than state-owned companies. Factors relate to the local market left a clear impact on the results for example gains or losses from foreign currency changes were the most influential component because of the huge imports from many countries. The second influential component was revaluation of available for sale securities because of the size of banks and the financial services institutions in the market whereas hedge for cash flow risk and pension liability proved to be a very weak practice by the Egyptian companies.
\end{abstract}

\section{Introduction:}

The Financial Accounting Standards Board issued standard No. 130 in 1997 about reporting comprehensive income. The standard requires companies to measure and present net income from operations and other comprehensive income items. In 2007, the IASB revised IAS No. 1 that and emphasized that a statement of comprehensive income should be issued separately as one of the compulsory financial statements. The comprehensive income statement should present net income and specific items 
that are produce "other income" and those items are: (1) Foreign currency translation gains or losses (2) gains or losses from revaluation of available- for- sale financial securities revaluation gains or losses of tangible or intangible assets (4) changes in market values of hedge contract and (5) actuarial gains or losses on employees' benefits' plan. Some arguments "for" the revised statement acknowledge that it is better to present to users of information the net income of the company from all sources. Views against, consider that it is better to show how much net income the company makes from the main business and it is helpful in evaluation the performance of the company -and the managers- to show that separately from gains (or losses) that result from market factors or other factors beyond control.

The Egyptian companies were required to issue a statement of comprehensive income starting from the financial year ended December 2016. There are some questions arise; for example, what is the importance of splitting those items in a separate statement? Does this help users in making decisions? As the previous overview on the Egyptian practice, although companies comply to the ministerial decree and present that statement, many companies did not have items of other comprehensive income to present, and ended up with comprehensive income of the year exactly the same as net income, so what is the benefit from preparing it? For other companies, only one item reported "gains or losses from foreign currency translation" and far below it comes gains or losses from available-for-sale financial securities, here another question relates to the informative value of the statement is: how much is the weight of each of those items in the comprehensive net income as a performance measurement to appear in that statement with that focus?

Egyptian companies started to prepare a separate statement for comprehensive income as a response to the ministerial decree No. 110 / 2015 and applied on the financial statements of 2016. This decree is issued to follow the issuance of the revised version of IAS No. 1 on 2007 effective from 2009. The revised version requires companies which adopt the IFRS to prepare two separate income statements; one is the income statement which measures net income from operations and the second is the comprehensive income statements measures all income. 
The writer argues that the main theme that describe these items is generating gains or losses due to accounting "valuation" processes rather than "doing business operations". It could be the reason behind showing these items in a separate statement to show the effect of these items on the overall net income which the company makes comparing to the net income from the main source which a company is established to do.

Arguments for this split of some "other income items" and showing them in a separate statement, are that; those items result from market forces and economic factors. For example, gains or losses from revaluation of available-for-sale securities relate to the size of investments in these securities and the changes in prices of bonds and shares in the market. Differences result from foreign currency translation are associated to the amount of operations in foreign currencies which companies involve in and the fluctuations in exchange prices between the local currency and the foreign currencies. Thus, factors like size of securities, activeness of capital market, size of transactions in foreign currencies, changes in exchange rates, undertaking hedge contracts, doing revaluation of assets and actuarial assessment of current pension liability; all those factors are the forces which generate the items of other comprehensive income which the revised standard asks companies to report in addition to net income from operations in the newly required statement. Furthermore, from examining reports about Egyptian companies, and individual annual reports of those companies, it is found that the type of industry and industry specifications also affect generating other comprehensive income items. Banks may affect gains or losses from securities, larger than manufacturing companies which could involve in larger operations in foreign currencies for instance. Therefore, the basic argument in this study centers around the existence and size of effect of these factors in the Egyptian companies. The following section examines literature relates to the usefulness of issuing comprehensive income statement generally, what purposes this may serve, and will provide a detailed discussion for the factors that are suggested to affect the measurement of comprehensive income. The examination targets to develop the research hypotheses and therefore is built upon literature and investigation into the practice by Egyptian companies. 


\section{Usefulness of measuring comprehensive income:}

It was the intention of the FASB from issuing the revised standard and asking companies to report compressive income in a separate statement was to provide additional information to the users of the financial information about the change in company's wealth between periods. The researcher argues that this change in income could arise from various causes that differ between industries. For example, company's comprehensive income may change due to changes in foreign currency rates. It could also rise or decline because of inflation/deflation waves which will certainly affect the valuation of assets and liabilities and this generates gains or losses from valuation processes that is added as an item of the comprehensive income. The question here is: do these factors have the same influence in the different industries? A bank for example, holds securities more than companies, so there is a bigger opportunity for it to make gains/losses from this investment larger than a service company for example. Here comprehensive income of a bank will be carried with gains/losses from investments in available for sale securities more than other companies.

The literature discussed and reported on different aspects regarding comprehensive income and in different environments. Biddle and Choi (2006) suggest that comprehensive income has a superior ability over traditional net income in explaining equity returns based on US data. Kanagaretnan et. al. (2009) found that comprehensive income was more strongly related with stock price and returns compared to net income in Canada. Several studies examined the value-relevance of comprehensive income in the revised format of IAS1 in 2007 such as the study of Pronobis and Zülch (2012) who found no evidence of superior predictive power for future firm performance by the comprehensive income over net income in the sample data of German companies that apply the IFRS. Their result applies to the aggregate comprehensive income and its components. More surprisingly, they found the predictive power for future firm performance by net income and comprehensive income has deteriorated after the adoption of IFRS revised standards.

Mechelli and Cimini (2014) examined the value relevance of net income comparing to comprehensive income after the mandatory adoption of the IASB standard by European countries. Their results indicate that net income is more value- relevant than comprehensive income. The results importantly reveal that issuing 
a statement of other comprehensive income has not produce significant change in the value relevance of both comprehensive income and total other comprehensive income. Writers state that these results apply to the overall data that represents many European countries, yet, some significant differences in the incremental value of the total other comprehensive income across countries which may be caused by the countries' characteristics. The same result was found by Bataineh and Rababah (2016). They found net income has more predictive power of future performance and future comprehensive income (itself) than comprehensive income when examined that on data for companies listed in Amman securities exchange- Jordan. The writers acknowledge that total comprehensive income has more informative content.

Schaberl and Victoravich (2015) found mixed results about the value relevance of other income based on management's representation of other income in financial statements. In their study, the value relevance declined in the companies which changed the reporting location of other income, from equity statement to a separate statement as a response to IASB updates. This was not the result did not appear in companies which continues in showing it in equity statement. Khan, Bradbury and Courtenay (2017) examined the value relevance of comprehensive income on a sample of companies in New Zealand. They test the proposition of the IASB behind issuing a statement to require comprehensive income to be presented in a separate statement on the hope to increase comparability of financial data and to make it understandable to users as supported by research on US data. The findings of Khan, Bradbury and Courtenay (2017) show a strong relationship between comprehensive income (comparing to net income) with stock price and returns due to the effects of the change of asset revaluation and the change in fair value of available for sale securities but not due to foreign currency translation gains or losses nor to hedge contracts. This results from non- US companies which apply the IFRS, are -in overallsupports the proposition of the IASB and show which items within the comprehensive income group caused that effect. Another study on New Zealand companies by Kabir and Fawzi (2011) found net income more persistent (not transitory between periods as the comprehensive income items) and explains contemporaneous stock returns better than total comprehensive income. The study found no significant difference between the two 
measures in terms of the predictive ability of returns and other comprehensive income is not incrementally value relevant.

A reader of this study could conclude that the properties which were evident to comprehensive income-comparing to net incomeare that it is more "annual-related" and does not move from one period to the next in general and in majority where as comprehensive income items are the opposite. The second property that is proved for it is being low predictive of returns and the third propriety is not having value relevant incremental to net income.

A study in Malaysia by Negad and Ahmad (2017) found that other comprehensive income and its component is value relevant and that statement of comprehensive income is more informative financial information. These results are based on tests in Malaysian market which is described by authors as less efficient than the market in developed countries. In the latter, the existence of active market makes fair value are required more and pursuit. The effects of fair value are reflected in items of comprehensive income components (e.g. revaluation of assets, hedge contracts, pension liabilities and others).

The findings of previous studies could rise doubt regarding the claims about the value relevance and informative ability of the newly adopted statement. Before assuming this further, the writer will examine the practice by the Egyptian company with regard to the details, items, size of comprehensive income components disclosed in the annual reports of those companies.

\section{Review of practice by Egyptian companies:}

Some observations can be made on the statements of 2016. All company listed in the Egyptian Securities Exchange (EGX) do prepare and show the statement of comprehensive income in its financial report. However, companies differ in the degree of details which it gives in that statements. For example, companies like 6 October for Development and Construction SODC, adds to net income of the year, just one figure expresses "total comprehensive items after taxes".

On the contrary, G B Ghabour Auto Company, Ezz for Steel give details of comprehensive items which are foreign currency translation differences. Mina for Pharmaceuticals \& Chemicals reports foreign currency translation differences and gains or losses of translating monetary items in foreign currency and deferred taxes on differences due to currency translation listed in 
the statement. Elsewedy Electric has one item only of that type; foreign operations currency translation. TMG (Talaat Mostafa Group), Suez Cement and Pioneers Holding report two items revaluation of available for sale investments and income tax of other comprehensive income- and detailed notes about them. Suez Cement is the only company which include re-measurement gains or losses on defined benefit plan.

Other companies prepare and publish the statement with no items inside it; e.g. Egyptian Telecommunication Company, Orange Egypt for Telecommunications, The Egyptian Company for Developing Construction's Materials, Juhayna Food Industries, Egyptian Resorts and Palm Hills for Construction have no items of that should be reported in that statement. In all practices, items of comprehensive income that are required to appear in the statement are added to net (operating) income of the year and the sum is divided between the controlling and noncontrolling parties as required by the standard. Both the review of literature and the examination of one year experience of the Egyptian company leads to drawing the first hypothesis in this study:

H1: Comprehensive income is weakly related to stock market price in the Egyptian market comparing to net income.

Factors affect comprehensive income:

To maintain with the scope of interest in this paper, this section elaborates on the industry, activities in foreign currencies, ownership and their effects on comprehensive income.

\section{I: Type of industry}

The researcher argues that the type of industry could have many implications on the measure of, the size, the significance and the component of comprehensive item as there are factors in each industry create these influences. Literature and practice sounds to support this idea. Many industries undertaken around the world regarding comprehensive income, carried industry-implications. For example, the by Bratten, Causholli and Khan (2016) reports that fair value adjustments included in other comprehensive income -in overall- can predict future earnings for one or two years ahead led by the capability of net unrealized gains or losses on available-for-sale securities while unrealized gains or losses on hedge contracts are negatively associated with future earnings. 
The tests on adjustments recorded in other comprehensive income for the period 2007- 2009 during the financial crisis, shows it could predict future profitability. This particular result contradicts with the criticism that fair value accounting forced banks in the US to record excessive downward adjustments.

The researcher considers testing the argument in a specific industry is important as it could reflect certain factors in that industry that distinctively affect the value relevance of comprehensive income. This appears in the findings of Bratten, Causholli and Khan (2016) where involving in financial investment is a major activity to the bank and available-for-sale securities is one of the major investment items in the portfolio of banks that is influential in size. Therefore, changes in market prices of these securities would in turn generate influential gains or losses from revaluation. That may not be the case in other manufacturing or service companies where involving in financial investments is a non-recurring activity with far less significant effect.

Another study in a specific industry is the investigation of the association between comprehensive income and future performance of the electric appliances industry in Japan by Tsuji (2013). The results of the study found comprehensive income is superior to other earnings or cash flow variables in predicting future stock earnings. The interpretation given by the author -in his own words- is that investors generally look at the bottom line figure in the profit and loss statement of Tokyo Stocks Exchange electric appliance industry firms.

In terms of The Egyptian practice, one may first highlight the main industries which constitute this economy. By examining the structure of industries in which companies listed in the Egyptian Securities Exchange operate in (as disclosed on Dec. 2017): 
Table (1) Companies listed in the Egyptian Securities Exchange -by industry

\begin{tabular}{|c|c|}
\hline Sector & $\%$ of market value of capital To the total \\
\hline Banks & 23.05 \\
\hline Natural Resources & 6.06 \\
\hline Chemicals & 9.55 \\
\hline Construction & 2.44 \\
\hline Financial Services (not banks ) & 8.17 \\
\hline Food and Beverage & 5.29 \\
\hline Health care and Pharma & 3.16 \\
\hline Industrial Products and cars & 9.22 \\
\hline Gas and Petroleum & 1.49 \\
\hline Home Appliances & 8.06 \\
\hline Real Estate & 10.83 \\
\hline Retail & 0.94 \\
\hline Media & 0.18 \\
\hline Technology & 0.31 \\
\hline Telecommunication & 9.43 \\
\hline Tourism and Leisure & 1.54 \\
\hline Utilities & 0.27 \\
\hline
\end{tabular}


This factual data in the table shows that about $30 \%$ of companies in Egypt are banks and financial services, this makes this industry dominating on the economic activities as it is the biggest portion of the market that works in one industry. It is bigger than industries like construction, steel, retails and others. This influential sector include banks either local banks (headed by National bank of Egypt, Banque Misr, Bank du Caire,...etc ), joint venture (like Arab African International bank), Branches of Arab banks (like the branches of Emirati banks Emirates Dubai, Abu Dhabi Islamic, Union Bank, A Mushreq...etc, Qatar National, Audi). There are also branches of international banks (like Credit Agricole Egypt, Barclays, HSBC, Citi). The huge operations of this sector and diversity and links to international markets and investors makes the characteristics of the sector very likely forceful on the measurement of comprehensive income. While there are no collective data available for the size of investment in available-for-sale securities in banks comparing to other sectors, one could look at the value at individual banks as indicator. For example, the investment in available-for-sale securities by Bank Misr L.E 49m while CIB Eg. Invested L.E 5.4 billion, National Union Bank invested L.E 32m at the end of 2016 as available for sale securities.

Bank of Alexandria in its balance sheet of June 2016 (i.e. on a semi annual level) equals EGP 1.4m, HSBC EGP 2.4m (the biggest type of its financial investments) in 2016. The value of these securities in the balance sheet of $\mathbf{2 0 1 6}$ for Talaat Mostafa Group Holding was L.E 93m, Ghabour Auto L.E 0.326m in June 2016, Ezz for Steel 109m of Sep. 2016. On the other hand, the industrial companies are expected to possess fixed assets of huge values, which will affect the item of revaluation gains or losses of tangible or intangible assets which is one item of comprehensive income.

This leads to developing the following hypothesis:

H2: The association between comprehensive income and stock price -comparing to net income- is affected by type of industry and firm size in the Egyptian market.

Besides the type of industry, the previous data also indicates that in the Egyptian companies, investments in available for sale securities differs in companies and tends to be seemingly smaller 
than other investments and this should affect the comprehensive income from that source.

\section{II: Transactions in foreign currency}

The standard requires reporting gains or losses from changes in exchange rates within the comprehensive income. The amount of this item depends on the size of operations done in foreign currency and the fluctuation versus stability of exchange rates between the Egyptian Pound and the international currencies. Regarding the size of operations in foreign currencies, the OEC report in 2016 refers to total exports of $\$ 22.4 b$ and imports of \$ 57.7b. Top exports destinations are to the UAE, KSA, Italy, Turkey and the UK. Top imports are from China, Germany, Russia, the UAS and Italy. The amounts of imports and exports with such various countries and more around the world suggests impacts of foreign currencies and the exchange rates between those currencies and the Egyptian Pound. Egyptian companies depend in the US dollar and the Euro heavily to settle deals with international parties and recently in 2016, Egypt and China signed an agreement to settle transactions in Chinese Yuan. This indicates the importance of changes in currency prices to Egyptian Pound and the gains or losses that could be reported in the comprehensive income.

In focus, the exploration above for companies' practice suggest that comprehensive income, seem to relate to the following factors:

-Having / and size of operations in foreign currencies.

-Having / and size of investment in financial securities that are available- for sale.

H3: Comprehensive income -comparing to net income- is affected more by the size of investments in available-for-sale securities and the operations in foreign currency.

Two main concerns to the writer in the experience of the Egyptian companies which newly prepare the comprehensive income statement are:

What is the relative effect of the "non- operating" sources of income that appear in the statement to the overall net income. That is, is the split of income into two statements and emphasizing 
the income for those items deserve that separation? Do we have influential amounts of operations in foreign currencies. Do Egyptian companies invest an influential amounts on available for sale financial investments? Influential hedge contracts and pension liabilities?

The main concern in this paper is of two folds; first to explore the content of the comprehensive income statement by Egyptian companies and which items most repeated. The second emphasize is placed on the value of this statement in terms of measuring income.

\section{The Research Hypotheses}

From the previous discussion, the researcher develops the following hypotheses for this study:

H1: Comprehensive income is weakly related to stock market price in the Egyptian market comparing to net income.

H2: The association between comprehensive income and stock price -comparing to net income- is affected by type of industry and firm size in the Egyptian market.

H3: The different components of comprehensive income has different contribution into the overall relationship between comprehensive income and the stock price.

The Investigation's design

The investigation covered the companies listed in Cairo Securities exchange, being the leading in the Egyptian economy and pioneers in responding to the regulations.

The researcher checked the latest available financial statements of these companies to maintain consistency in data used. This led to depending on data for 154 Firms. The companies vary in size and work in different industries range from steel, construction, cement, ceramic, banks and others as indicated in table below: 
Table 1: Distribution of companies $d$ in the study by industry

\begin{tabular}{|ll|}
\hline Industry & \% OF TOTAL \\
\hline Banks & 21.71 \\
Basic Resources & 6.04 \\
Chemicals & 8.27 \\
Construction and Materials & 3.6 \\
Financial Services excluding Banks & 8.53 \\
Food and Beverage & 5.56 \\
Healthcare and Pharmaceuticals & 1.92 \\
Industrial Goods and Services & and \\
Oil and Gas & 1.49 \\
Personal and Household Products & 6.72 \\
Real Estate & 11.23 \\
Retail & 0.74 \\
Media & 0.14 \\
Technology & 1.23 \\
Telecommunications & 10.91 \\
Travel \& Leisure & 2.86 \\
Utilities & 0.29 \\
\hline
\end{tabular}

These industries were grouped further in the research to maintain the distinction focused. Therefore, companies belong to banks and financial services combined in one group. Basic resources, chemicals, construction and materials, industrial goods and real estate were made one group. Retail, media, technology and utilities were assembled in one group and the remaining left each individually. The grouping took into consideration the -somehowcloseness in activity, similarity in industry and market conditions.

As the Egyptian companies prepare and publish the Comprehensive income statements starting from the financial year 2016, the researcher depended got the data about stock prices were collected from Cairo Securities Exchange and the financial measurements of the companies were collected from the annual reports for that year.

\section{Testing Hypotheses}

The research hypotheses were tested via models selected from the literature as explained below. 


\section{The Method}

The arguments will be tested via Ohlson (1995) model and other studies (e.g., Khan et. al. 2017, Dhaliwal et al. 1999), to examine the value relevance of comprehensive income comparing to net income, by the model:

$$
\begin{aligned}
& P j t=\alpha 0+\alpha 2 N I S j t+\varepsilon j t \quad(1) \\
& P j t=\alpha 0+\alpha 1 C I S j t+\alpha 2 N I S j t+\varepsilon j t
\end{aligned}
$$

Where; $C I$ Sjt is the comprehensive income as suggested by the new standard; and $P j t=$ price per share; $N I S S=$ annual net income after taxes

To examine the components of other comprehensive income incremental to net income, we also report an extended version of equation (2)) replacing $C I \_S$ with the component of other comprehensive income which makes the difference between NI and CI (Dhaliwal et al. 1999; Kanagaretnam et al. 2009):

$P j t=\alpha 0+\alpha 1 O C I S j t+\alpha 2 N I S j t+\alpha 3 F C T S j t+\alpha 4 A R S j t+\alpha 5 S G L S j t+$ $\alpha 6 C F H$ Sjt $++\alpha 6 P L S j t+\varepsilon j t$

where $F C T \_S=$ the change in cumulative foreign currency translation adjustments; $A R \_S=$ the change in assets revaluation reserves; $S G L \_S=$ the gains/losses due to the change in fair value of available-for-sale securities; $P L \_S=$ Pension liability and CFH_S = the gains/losses due to the change in the fair value of cash flow hedge reserves.

\section{Results}

For the sample as a total, preliminary results in table (1) show that $p$-value of coefficient and the value of $F$ of comprehensive income are significant (model 1 and 2 ) and higher than that of net income. Data suggest that the share prices affected by measuring other comprehensive income in the companies tested in overall. Adjusted $R 2$ for model 1 and 2 are 0.462 and 0.438 respectively. $P$ values in the two models are significant (at confidence interval 95\%). Also $\alpha 1$ associated to other comprehensive income is higher than that of net income. Thus hypothesis 1 is accepted. 
Table 2: Results summary

\begin{tabular}{|l|l|l|}
\hline Group of industries & \multicolumn{2}{|l|}{$\begin{array}{l}\text { Model 1 } \\
\text { Adjusted R2 }\end{array}$} \\
\hline For overall data & $\mathbf{0 . 4 6 2}$ & 0.04 \\
\hline Group of industries & $\begin{array}{l}\text { Model 2 } \\
\text { Adjusted R2 }\end{array}$ \\
\hline For overall data & 0.41 & 0.032 \\
\hline
\end{tabular}

Tests were re-undertaken for every sector individually and the results varied, as shown in the table below:

Table 3: Results by sector

\begin{tabular}{|c|c|c|}
\hline Group of industries & Adjusted R2 & F value \\
\hline $\begin{array}{l}\text { For overall data } \\
\text { For individual group of industries: } \\
\text { Banks and financial services } \\
\text { Basic resources, chemicals \& } \\
\text { construction } \\
\text { Retail, media, technology and } \\
\text { utilities } \\
\text { Food and Beverage } \\
\text { Health care } \\
\text { Oil \& Gas } \\
\text { Personal and Household Products } \\
\text { Travel \& Leisure }\end{array}$ & $\begin{array}{l}0.56 \\
0.28 \\
0.43 \\
0.36 \\
0.33 \\
0.54 \\
0.42 \\
0.22\end{array}$ & $\begin{array}{l}\text { 0.0028 } \\
\text { 0.05 } \\
\text { 0.038 } \\
\text { 0.061 } \\
\mathbf{0 . 0 6 3} \\
\mathbf{0 . 0 0 7} \\
\mathbf{0 . 0 5 2} \\
\mathbf{0 . 0 7 8}\end{array}$ \\
\hline
\end{tabular}

Results suggest that the second hypothesis is supported. There are differences in the influence of comprehensive income in its relation to share price stems from the type of industry. The group of companies that belong to banks and financial services show the highest significance of reporting comprehensive income (R2 0.56 the highest) followed by oil and gas companies then retail, media and utilities and personal and household products.

Comprehensive income was much significant in these companies as well in predicting share price (as $F=0.0028,0.007,0.038$ and 0.052 respectively). 
Differences in industries are evident. Banks and financial services sector is highly affected by the issuance of statement of comprehensive income statement where an influential portion of transactions include dealing in financial securities and involves heavily in buying and selling of available for sale ones in addition to dealing in foreign currencies thereby measuring and showing details about these items in a separate statement when measuring income, would be more informative to investors.

The least affected is travel and leisure sector which suffers weak performance in overall over the last eight years due to local conditions. In between the most affected and the least, comes sectors like basic resources, chemicals and construction which is shown to be active in its investments. The country witnesses a boom in the size of operations and projects in that field which leaves little investments by this sector in financial securities. Also a good portion of production resources for that sector is collected from the local market like steel, cement and ceramic. This means less exposure to foreign currency effects/ less gains or losses, comparing to a sector like health care which imports a huge percentage of medical supplies or oil and gas where the vast majority of the amount consumed are imported.

Companies belong to the private sector shown more influence of comprehensive income than the state-owned companies. This supports the part of hypothesis 2 regarding the effect of ownership. However, the biggest portion of companies listed and examined belong to the private sector which has more flexible management systems, more dynamic involvements in different industries and in different markets internally and abroad. These features do not avail to the tightly constrained state-owned companies. These factors have implications in the size of effect of involving in operations in foreign currencies, in adopting hedge tools and in taking investment decisions in available for sale securities or not. This makes the basket of "other comprehensive income" rich in components and bigger in size.

When the items of other comprehensive income were examines in its influence, the following results were gained: 
Table 4: Results of the influence of the individual components of comprehensive income

\begin{tabular}{|c|c|c|}
\hline Group of industries & Adjusted R2 & F value \\
\hline $\begin{array}{l}\text { Foreign currency translation } \\
\text { adjustments } \\
\text { Assets revaluation reserves } \\
\text { Gains/losses due to the change in fair } \\
\text { value of available-for-sale securities } \\
\text { Gains/losses due to the change in the fair } \\
\text { Value of cash flow hedge reserves. } \\
\text { Pension liability }\end{array}$ & $\begin{array}{l}0.68 \\
0.52 \\
0.63 \\
\\
0.32 \\
\\
0.21\end{array}$ & $\begin{array}{l}\text { 0.0035 } \\
0.07 \\
0.031 \\
0.05 \\
\\
0.08\end{array}$ \\
\hline
\end{tabular}

Results show that in the Egyptian market, the effects of changes in foreign currency is largely significant and influential. This is because of the big percentage of imports' operations which almost all sectors do. In addition, the country passed by a big shift in the financial policy two years ago where the exchange rate between the Egyptian Pound and the major international currency almost all companies use in settling transaction, the US dollar. After huge increases in the dollar rate, the government moved to free market/floated rate and limited the exchange of foreign currencies to banks only to control the increases in currency prices. There is no difference between sectors regarding this. All companies in all industries are tightly linked to the changes in dollar price to the Egyptian Pound. The effect extends to almost all products and was not limited to one or more industry. The reasons for that are the huge amount of imports and the links or extended effects between industries. As the OCE (https://atlas.media.mit.edu/en/profile/country/egy/) disclose in 2016

top exports of Egypt are Gold (\$2.65B), Crude Petroleum (\$1.81B), Refined Petroleum (\$802M), Nitrogenous Fertilizers $(\$ 767 \mathrm{M})$ and Insulated Wire $(\$ 740 \mathrm{M})$, Gas $(\$ 3.2 B)$. Major imports include Cars (\$2.49B), Packaged Medicaments $(\$ 1.71 B)$ and Wheat $(\$ 1.54 B)$.

The top export destinations of Egypt are the United Arab Emirates (\$2.83B), Saudi

Arabia (\$1.75B), Italy $(\$ 1.47 B)$, Turkey $(\$ 1.44 B)$ and the United $\underline{\text { Kingdom }}(\$ 1.05 B)$. The top import origins are China $(\$ 10.4 B)$, Germany $(\$ 5.01 B)$, Russia $(\$ 3.78 B)$, the United States $(\$ 3.48 B)$ and Italy $(\$ 3.42 B)$.

This gives an idea about the size and variation of foreign currencies the Egyptian economy involves in. 
After this component come the gains/losses due to the change in fair value of available-for-sale securities and this is led by the banks and financial services companies mainly (together makes about $30 \%$ of the companies listed in the Egyptian Securities Exchange). This does not exclude that companies from other sectors invest in securities in addition to Arab and foreign investors as well. For other companies, they might involve in transactions of financial securities but other sectors are not active in doing that investments as banks and the financial services companies.

The following influential component in the other comprehensive group, is the assets revaluation. Egyptian economy was close to be described as "hyper inflationary" over the last two years. Companies tended to revalue assets and this is what rose the influence of this component. However, Egyptian companies are obliged to follow the IFRS, and hence adopt its guidelines relate to the circumstances in which gains or losses are recognized.

The other components were weak and minor in appearing in the financial statements. This suggests that cash flow hedge is a financial instrument that limitedly reported by Egyptian companies.

\section{Summary:}

The study compared between the effects of net income and comprehensive income in changes in share price. Companies from Egyptian securities exchange were examined and the results support the main hypothesis which is, comprehensive income more related to share price than net income. Details show that the situation differs by industry and ownership. The results are stronger in banks and the financial sector and industrial companies rather than a sector like food or tourism. Companies of the private sector showed more influential impact than stateowned companies. Within the components of other comprehensive income, some items were more active than other. Results show that gains or losses from foreign currency and from revaluation of available for sale securities are more active than hedge for cash flow and pension liability. 


\section{References:}

Biddle G. and J. Choi, Is comprehensive income useful? Journal of Contemporary Accounting \& Economics, Volume 2, Issue 1, June 2006, PP: 1-32.

Mechelli A. and R. Cimini, Is Comprehensive Income Value Relevant and Does Location Matter? A European Study, Journal of Accounting in Europe, Volume 11, Issue 1, 2014, PP: 59-87.

Kanagaretnam K., R. Mathieu and M. Shehata, Usefulness of Comprehensive income reporting in Canada, Journal of Accounting and Public Policy, Volume 28, Issue 4, Aug. 2009, PP: 349- 365.

Pronobis P. and $H$ Zülch, " The Predictive Power of Comprehensive Income and its Individual Components under IFRS", Problems and Perspectives in Management , $16^{\text {th }}$ Nov. 2012.

(https://papers.ssrn.com/sol3/papers.cfm?abstract_id=1576384 as of $28^{\text {th }}$ July 2017

Bataineh A. and A. Rababah, Comprehensive Income and Net Income, Which is more powerful in predicting Future Performance, International Journal of Academic Research in Accounting, Finance and Management Sciences, Vol. 6, No.2, April 2016, pp. 114-120.

Schaberl P. and L., Victoravich, "Reporting Location and the Value Relevance of Accounting Information: The Case of Other Comprehensive Income, Advances in Accounting, Volume 31, Issue 2, Dec. 2015, PP: 239-246.

Khan S, M. Bradbury and S. Courtenay, "Value Relevance of Comprehensive Income", Australian Accounting Review No. 00, Vol. 00, Issue 0, 2017, PP: 1-9.

Kabir H. and L. Fawzi, "Properties of Net Income and Total Comprehensive Income: New Zealand Evidence", Accounting Research Journal, Vol. 24 Issue: 3, 2011, PP: 268-289. 
Negad M. and A. Ahmad, "Value Relevance of available-for-sale financial instruments (AFS) and revaluation surplus of PPE (REV) components of other

comprehensive income", SHS Web of Conferences 34, 03004 (2017)

(https://www.shs-

conferences.org/articles/shsconf/pdf/.../shsconf four2017 03004.p

df as of 28 July. 2017).

Bratten B., M. Causholli and U. Khan, "Usefulness of Fair Values for Predicting Banks' Future Earnings: Evidence from Other Comprehensive Income and its Components", Review of Accounting Studies, Vol. 21, No. 1, 2016, PP: 280-315.

Tsuji C., "An Investigation of Comprehensive Income and Firm Performance: The Case of the Electric Appliances Industry of the Tokyo Stock Exchange", Accounting and Finance Research, Volume 2, No. 2, 2013, PP: 29- 35.

Bataineh A. and A. Rababh, "Comprehensive Income and Net Income, Which is more Powerful in Predicting Future Performance", International Journal in Academic Research in Accounting, Finance and Management Science, Volume 6, No. 2, April 2016, PP: 114- 120.

OCE (https://atlas.media.mit.edu/en/profile/country/egy/) as of 12/11/2017.

Business Times "Egypt, China sign currency swap deal", Dec. $7^{\text {th }}$, 2016

(https://www.businesstimes.com.sg/government-economy/egyptchina-sign-currency-swap-deal)

The Egyptian Securities:

http://www.egx.com.eg/Arabic/MarketWatchSectors.aspx as of Dec 2017) 